\title{
U.S. INCOME TAXATION OF NEW FINANCIAL PRODUCTS
}

\begin{abstract}
This paper discusses the response of the U.S. federal income tax to financial innovation. Income taxation in the U.S. and elsewhere has traditionally relied on distinctions, such as the difference between fixed and contingent returns, that can be undermined by new financial products. The principal tax law responses to innovative products have been: (1) transactional analysis, which aggregates or disaggregates new transactions to conform them to existing legal categories, (2) taxation of changes in market value, rather than realization events, (3) taxation based on an assumed formula, and (4) anti-avoidance administrative approaches.
\end{abstract}

Alvin C. Warren, Jr Harvard Law School

Cambridge, MA 02138

tel: 617-495-3186

fax: 617-496-4880

e-mail: warren@law.harvard.edu 
The fundamental problem addressed in this paper is that income taxation has relied on distinctions that can be undermined by financial innovation. Part I explains the problem. Part II describes the response of the U.S. tax law in recent years to new financial products, as well as proposed alternative solutions. Part III summarizes and offers some tentative conclusions. The potential for financial innovation is obviously enormous, so the transactions analyzed in this paper are necessarily illustrative, and have been chosen to convey the tenor of recent developments. ${ }^{1}$

\section{The Problem}

This section reviews three points: (a) realization income taxation has traditionally relied on a distinction between fixed and contingent returns to determine when income is taxed, (b) financial theory demonstrates that this distinction may not be tenable in practice, and (c) the U.S. income tax relies on other distinctions that may also be undermined by innovative financial contracts.

\section{A. Realization Income Taxation}

\section{Fixed-Return Instruments}

Although in theory an income tax might be based on changes in the values of assets, considerations of administrability, liquidity, and political acceptability have produced a tax that is generally triggered by certain events, usually known as realization

\footnotetext{
1 This paper brings up to date developments discussed in Warren (1993).
} 
events. As illustrated by the following example, the income tax nevertheless requires taxation of income prior to receipt of cash in the case of debt with fixed returns:

Example 1: A corporation issues a bond that will pay the holder $\$ 133$ in three years. No interest is payable on the obligation, which is therefore known as a zero coupon bond. An investor buys the bond from the issuing corporation for $\$ 100$.

The bond in example 1 is said to have original issue discount (OID) because the stated redemption price at maturity (\$133) exceeds the issue price $(\$ 100)$. The difference is spread over the three years by first determining that rate of interest, known as the yield-to-maturity, which would compound the amount invested to the stated redemption price. ${ }^{2}$ In our example, the yield-tomaturity is $10 \%$ because $\$ 100 \times(1.1)^{3}=\$ 133$, assuming annual compounding for simplicity, as we will throughout the paper. That yield is then applied annually to the compounded value of the investment, so $\$ 10$ is taxable in year $1(.1 \mathrm{x} \$ 100), \$ 11$ in year 2 $(.1 \times \$ 110)$, and $\$ 12$ in year $3(.1 \times$ \$121).

The rationale for this treatment is straightforward: the asset will increase in value to a known amount, and yield-to-maturity is a financially appropriate way to distribute that increase over time. Including OID in income can be thought of as the mirror image of deducting depreciation. Similar provisions reduce interest inclusions and deductions for instruments purchased at a

\footnotetext{
2 Internal Revenue Code of 1986, as amended, \$1272 (hereinafter IRC).
} 
premium. ${ }^{3}$

If the issue price of a fixed-return financial instrument is unknown, because the instrument is not publicly traded and is acquired in exchange for nonmarketable property, the issue price is derived by discounting the stated redemption price at maturity, using an interest rate determined by the term of the contract. That rate then determines the amount to be included annually. Yield-to-maturity taxation, which was not enacted until 1982, does not apply to discount that arises after issuance. Such market discount does not have to be recognized until maturity or disposition of the instrument, with deductions for interest paid to purchase or carry such instruments also deferred. ${ }^{4}$

Even where there is OID, yield-to-maturity taxation involves something of a compromise, because it assumes a single rate of interest over the entire contract period, masking any difference in rates for difference parts of the period. Moreover, the yield-tomaturity system does not take into account changes in the value of the bond after purchase. Some commentators [e.g., Strnad (1995), Gergen (1994)] have suggested that the possibility of selectively realizing losses while deferring gains allows taxpayers to eliminate much of the effect of taxing oID currently.

\section{Contingent-Return Instruments}

\footnotetext{
3 IRC $\$ \$ 163(2), 171$.

4 IRC $\$ 1276-77$.
} 
The foregoing treatment of original issue discount is to be contrasted with the taxation of an asset on which the returns are not fixed. The purchase, for example, of corporate stock on which no dividends are paid does not produce any income tax consequences until the stock is sold or otherwise disposed of. Once again, the rationale for this result is straightforward: whether or not any payments will be received is uncertain. In the absence of annual revaluation of all assets, imposition of the income tax has had to wait until the gain or loss is realized through sale or other disposition. This wait-and-see approach applies generally to assets with contingent, rather than fixed, returns, including forward contracts and options.

Because the last two categories of contracts are particularly important in the discussion that follows, a very brief review of their characteristics and current taxation may prove helpful. ${ }^{5} \mathrm{~A}$ forward contract is an executory agreement to sell a specified asset at a currently agreed price on a certain date in the future. (A forward contract that is standardized and traded on an exchange is usually known as a future.) In general, no money changes hands at the time forward contracts are written, and there are no tax consequences until gain or loss is realized on performance or disposition of the contract.

Under an option contract, one party has the right, but not the

\footnotetext{
5 For more on the institutional details of these contracts, see Cox (1985) and Hull (1993). For more on the details of current tax law, see Kramer (2000), Colon (1999b), and Keyes (1997).
} 
obligation, to buy or sell a specified asset in the future for a price fixed at the time the contract is agreed to. The right to buy is generally known as a call option, and the right to sell is known as a put option. Unlike a forward contract, the party undertaking the obligation to buy or sell, the writer of the option, receives a payment, generally known as a premium, as consideration at the time the obligation is entered into.

The purchase of an option is treated as a capital expenditure, and there are generally no tax consequences to either party until its exercise or disposition. If the option lapses without exercise, the option writer is treated as if he had sold the option. If a call is exercised, the writer includes the premium in the amount realized on the sale of the asset, and the holder of the call includes the premium in cost basis. If a put is exercised, the writer reduces cost basis by the amount of the premium, and the holder of the put reduces amount realized by the same amount. If an option is sold prior to exercise, gain or loss is recognized, with the nature of the gain generally determined by that of the underlying asset.

Finally, many forward contracts and options are written for settlement by a cash payment from one party to the other on the date of performance, rather than by the actual delivery of the property specified in the contract. Such payments with respect to these cash settlement options or forward contracts are taxable events. 
To recapitulate, income is taxed annually on a yield-tomaturity basis on certain financial assets with fixed returns, whereas a wait-and-see approach has traditionally been applied to assets with contingent returns. Whatever one thinks of the fairness and efficiency consequences of this dual regime, it is workable only if the two categories of assets can be distinguished.

\section{B. Financial Equivalences}

Financial theory suggests that the tax law distinction between fixed and contingent return assets is not tenable, because financial equivalences sometimes permit one category of asset to be replicated using the other. We will illustrate this possibility using the well-known concept of put-call parity. [See stoll (1969) and Merton (1973a)].

Consider the following four assets: (1) a share of stock that does not pay dividends, (2) a risk-free zero coupon bond, (3) a call option to buy a share of the specified stock, and, (4) a put option to sell a share. Of these four assets, only the second, the bond, is subject to taxation under the yield-to-maturity regime applicable to fixed returns. The return on the stock, call, and put is uncertain and therefore subject to wait-and-see income taxation.

There is, however, a fundamental relationship among these four assets that allows each to be restated in terms of the others, as long as adequately competitive markets exist for each. Suppose that the strike price at which the put and call can be exercised is 
the same as the amount payable in the future under the bond, and the date at which the put and call can be exercised is the same as the date on which the bond will be paid. The put-call parity theorem states that the values of the stock (S), bond (B), call (C), and put (P) on the exercise date must satisfy the following relationship, ignoring transactions costs and credit risks:

$$
S+P=B+C
$$

An investor who holds both a share of stock and a put at a strike price of $\mathrm{K}$ will at the date of exercise have assets worth $\mathrm{S}$ but no less than $K$, because he will exercise the put if $S$ is less than K. Similarly, an investor who holds a bond that will pay $\mathrm{K}$ on the exercise date and a call at a strike price of $\mathrm{K}$ is guaranteed the value of $\mathrm{K}$ on that date; if $\mathrm{S}$ is then greater than $\mathrm{K}$, he will exercise the call to receive stock with the value of $\mathrm{S}$. If the stock plus a put must equal the bond plus a call on the exercise date, the two positions must also be equal in value before that date if there are competitive markets for each contract. Otherwise, an arbitrager would sell the more expensive position and acquire the cheaper position to obtain a riskless windfall to the extent of the difference in value.

Put-call parity suggests that a synthetic share of stock can be created by purchasing a zero coupon bond and a call, while writing a put:

$$
S=B+C-P
$$

Similarly, a synthetic zero coupon bond can be created by 
purchasing a share of stock, writing a call and buying a put:

$$
B=S-C+P
$$

At this point, the theoretical challenge presented by put-call parity to the income tax distinction between fixed and contingent returns should be apparent. If modern financial practice will permit the creation of a synthetic share of stock, an issuing corporation could achieve interest deductibility on the bond portion of the position, even though dividend payments on actual shares of stock are not deductible. Synthetic debt, on the other hand, would avoid application of the OID provisions, because none of the components of the synthetic position would be taxed until realization. Indeed, taxpayers could combine opposing positions in, say, actual and synthetic debt to eliminate any financial outcomes other than the net tax result, which could be applied to defer taxes on other income.

Put-call parity is not the only financial equivalence that undermines the income tax distinction between fixed and contingent return assets. Readers familiar with the Black-Scholes model for option pricing [Black and Scholes (1973), Merton (1973b)] will recognize the equivalence at any given moment between (a) borrowing and buying a certain amount of stock, and (b) buying a certain number of calls on the same stock. Intuitively, the stock and debt combination behaves like a call because the downside risk is eliminated if the minimum expected value of the stock just covers the amount of debt, while the upside potential is maintained when 
the value of the stock exceeds that amount. At any given moment, there is therefore a combination of borrowing and stock ownership that is equivalent in outcome to owning an option on the stock. This equivalence can thus also be used to construct a synthetic call by combining a changing amount of borrowing with changing amount stock, a process that is sometimes called dynamic hedging. [Rubinstein and Leland (1981)]

To summarize, modern financial theory has identified certain equivalences that allow different types of assets to be reconstructed in terms of each other. The most striking implication of these relationships for income tax policy is that, to the extent made operational, these equivalences would undermine the fundamental distinction between assets on which there are fixed returns and those on which there are not.

\section{Other Income Tax Distinctions}

The discussion so far has focused on timing of income under a realization income tax. There are, however, many other distinctions that have important consequences under U.S. tax law, which distinctions may also be circumvented with innovative financial contracts. In addition to timing issues, the discussion of U.S. developments below will include issues of (1) character (whether ordinary income or capital gain); (2) source (whether domestic or foreign); and (3) debt versus equity (which determines whether investment income is also subject to the corporate tax).

\section{Current and Proposed Solutions}


The tax law discontinuities described above have provoked four different solutions in recent years: (a) elimination of

differential treatment through transactional analysis, (b) taxation of changes in market value, (c) formulaic taxation, and (d) antiavoidance provisions.

\section{A. Transactional Analysis}

The traditional U.S. tax law approach to discontinuities such as those identified above has been to analyze the components of a new transaction in order to achieve consistent treatment with other, more familiar, assets. We will illustrate the traditional approach by considering the development of the U.S. tax law in recent years with respect to nine transactions: income strips, notional principal contracts, hybrid instruments, related positions, debt exchangeable into corporate stock, conversion of ordinary income into capital gain, derivatives on a corporation's own stock, payments to foreign investors, and foreign currency transactions.

\section{Income Strips}

Example 2: The owner of an income-producing asset sells the right to receive the income from the asset for ten years to an unrelated third party.

The tax law has developed two different approaches to the transaction in example 2.6 The first is the coupon stripping

6 In addition to these two general approaches, some income stripping transaction might be subject to anti-avoidance statutory provisions (e.g., IRC $\$ 167(e)$ (disallowing amortization in the case of related parties); IRC $\$ 7701(1)$ (allowing recharacterization of certain conduit arrangements)) and judicial doctrine that prohibit "assignment of income." 
approach, which has applied to bonds since 1986.7 Under this

approach, the seller allocates his cost basis between the sold and retained interests, recognizing gain or loss on the sale. Stripped interest and principal are then treated as OID instruments, so income is accrued on each. In 1993, this approach was extended to purchasers of stripped preferred stock. ${ }^{8}$

The second, deemed financing, approach recharacterizes the sale in example 2 as a loan, so that the "seller" of the income interest continues to recognize income on the underlying property. This approach was originally developed for strips of mineral

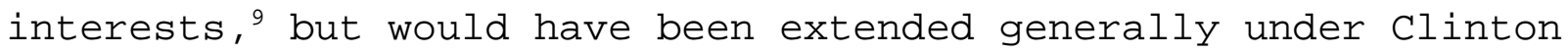
Administration proposals to leases, service contracts, stock, and other property. (Joint Committee, 2000)

\section{Notional Principal Contracts}

A notional principal contract is an arrangement under which payments are made with respect to a notional amount, which amount itself never changes hands. A simple interest-rate swap and cap are illustrated in the following examples:

Example 3: Taxpayers A and B enter into a five-year contract under which A is obligated to pay $B$ interest annually computed at the fixed rate of $10 \%$ on a notional amount of $\$ 100$, while $B$ is obligated to pay A interest annually on the notional principal amount of $\$ 100$ at a standard floating rate, such as the prime rate. The only cash that actually changes hands is the net payment due each year.

\footnotetext{
7 IRC $\$ 1286$

$8 \operatorname{IRC} \$ 305(e)$.

9 IRC $\$ 636$.
} 
Example 4: C promises to pay D the excess of the prime rate over 10\% times a notional principal amount of $\$ 100$ each year for the next three years. In exchange, D pays C a specified dollar amount when the contract is entered into.

Swaps, caps, and other notional principal contracts are now subject to elaborate Treasury regulations issued in $1993 .{ }^{10}$ Speaking very generally, periodic payments (paid at an interval of a year or less) are recognized in the year to which they pertain. Such payments are therefore treated roughly like interest payments with respect to offsetting loans for the notional amount. Nonperiodic payments are treated in accordance with their "economic substance," which generally means that they are included and deducted in some manner over the life of the contract. For example, substantial nonperiodic payments on swaps may be disaggregated either into a loan and a swap or into a series of cash-settled forward contracts. Nonperiodic payments relating to caps may be treated like a series of cash-settled options. Finally, termination payments are generally taken into account on termination.

These provisions are intended to treat notional principal contracts like other similar transactions, which themselves are not always taxed consistently. A swap, such as that illustrated in example 3, can be disaggregated into a series of cash-settled forwards, which takes into account the term structure of interest rates. As indicated in the previous paragraph, that is indeed is

10 Treas. Reg. $\$ 1.446-3$. 
the treatment of a swap with substantial nonperiodic payments. On the other hand, an on-market interest rate swap (which does not involve nonperiodic payments) is treated like fixed-return debt, which uses a single, blended rate of interest over the entire period.

\section{Hybrid Instruments}

Hybrids combine elements of traditional instruments, so transactional analysis might involve disaggregating the new instrument into its components, which would then be taxed as though they had been issued separately. The tax law has encountered considerable difficulty with this approach, in part because different disaggregations could give rise to different tax results. This difficulty is illustrated by the experience with debt with embedded options:

Example 5: An entity issues a five-year stock index growth note (SIGN) with a stated indebtedness of $\$ 1000$. In five years, the holder will receive back her investment of $\$ 1000$, plus $\$ 1000$ multiplied by the percentage increase in the Standard and Poor's Index of 500 stocks (S\&P 500), if any. Accordingly, if the index doubles, the holder will receive a total of $\$ 2000$. The holder is guaranteed a minimum payment of $\$ 1000$, even if the index declines. No interest is payable on the indebtedness.

In 1991, the Treasury proposed that the index-linked note in example 5 be disaggregated (or "bifurcated," as lawyers like to say) into a zero coupon bond and a call option, with interest taxed over the five years on the zero coupon bond component. ${ }^{11}$ Assuming an interest rate of $10 \%$, the value of the zero coupon bond at issue

\footnotetext{
11 Prop. Treas. Reg. \$ 1.1275-4(g)(1), 56 Fed. Reg. 8308, 8310 (1991).
} 
would be $\$ 1000 /(1.1)^{5}$, or $\$ 621$. The remaining $\$ 379$ paid by the holder would be considered the premium for the embedded option. As a result of this disaggregation, $\$ 379$ of original issue discount on the bond would be included on a yield-to-maturity basis over five years, with gain or loss on the option component taken into account at the end of that period.

There is, however, more than one way to disaggregate the instrument in example 5. One alternative would be to conceptualize the index-linked note as a loan of $\$ 1000$ at a market rate of interest, plus a forward contract obligating the lender to exchange the compounded interest for the excess, if any, of the S\&P 500 over \$1000 at the end of five years. Under this approach, interest should be imputed on the entire $\$ 1000$ over the five years, with the gain or loss on the contingency taken into account at the end of the period. In 1993, the Treasury proposed new regulations under which interest would be imputed on the entire purchase price of the stock index note. ${ }^{12}$ These regulations were, however, withdrawn before official publication as part of the transition to a new administration.

Although consistent with the tax treatment of a note plus a cash settlement forward contract on the S\&P 500, this last approach is inconsistent with the treatment of a taxpayer who independently purchased an option and a zero coupon bond, because no interest

12 I.R.S. Notice of Proposed Rulemaking, Relating to Tax Treatment of Contingent Payment Debt Instruments, Daily Tax Report L-9, \$ $1.1275-4$ (b) (Jan. $21,1993)$. 
would be imputed on the purchase price of the option. Moreover, if the issuer of a stock index note offset its exposure to increases in the S\&P 500 by purchasing an option, it could deduct interest imputed on the option portion of the issue price, while not including any imputed interest on its hedged option, which is subject to wait-and-see taxation. Accordingly, the 1993 proposal would not have applied to hedged issuers.

Finally, put-call parity indicates yet another way the instrument in example 5 could be disaggregated, because a zero coupon bond plus a call will yield the same results as owning the underlying asset plus a put. That is, the same results as those in example 5 could be obtained by purchasing $\$ 1000$ worth of S\&P 500 index units as well as five-year puts at a strike price equal to the initial value of the index. When viewed separately, neither of those assets would involve fixed payments subject to yield-tomaturity taxation.

Disaggregation was eventually abandoned with respect to this type of instrument, which in now subject to a version of formulaic taxation discussed below.

\section{Related Positions}

For the synthetic debt or synthetic stock described above, transactional analysis might mean identifying and integrating the positions that added up to the traditional instrument, and then taxing the sum of the position. Current law has not developed a general rule of aggregation along these lines, although there are 
many instances in which taxpayers are required or permitted to integrate particular positions. Four examples are the statutory provisions now applicable to wash sales, straddles, business hedges, and certain appreciated financial positions.

a. Wash Sales: Losses on stock and securities have been disallowed for many years when the taxpayer acquires substantially similar stock or securities within thirty days. ${ }^{13}$

b. Straddles: Losses related to unrealized gains on certain offsetting positions in actively-traded personal property have been disallowed since 1981, ${ }^{14}$ with interest and carrying charges attributable to such positions subject to capitalization: ${ }^{15}$

Example 6: On December 1, 1985, E enters into a contract to buy a certain quantity of wheat on a specified date in the future (a long position). At the same time $E$ enters into a contract to sell the same quantity of wheat on the same date (a short position). On December 10, 1985, E disposes of the short position at an loss of $\$ 11$, at which time there is $\$ 11$ of unrealized gain in the offsetting long position. Prior to 1981, taxpayers would argue that they could use the \$11 of loss to offset other income, while ignoring the \$11 gain until realized. Under current law, the $\$ 11$ loss would be disallowed in 1985 because there is $\$ 11$ of unrecognized gain in the offsetting long position.

c. Business Hedges: Transactions that hedge risk incurred in producing ordinary income could, under the usual provisions applicable to such transactions, produce capital gain or loss. In order to eliminate the resulting discontinuities, the Internal Revenue Code has since 1999 permitted matching of gains and losses

\footnotetext{
13 IRC $\$ 1091$.

14 IRC $\$ 1092$.

15 IRC $\$ 263(\mathrm{~g})$.
} 
in hedges. ${ }^{16}$

d. Certain Appreciated Financial Positions: Taxpayers have long sought methods of "monetizing" gain on appreciated positions without realizing gain for tax purposes, including short sales against the box:

Example 7: Investor I purchases 100 shares of X corporation in 1961 for $\$ 40$ a share. In 1991, when the share price is $\$ 70$, I borrows 100 X shares from a broker and sells them. In 1995, when the share price is $\$ 50$, I delivers his I shares to the broker.

Taxpayers took the position that the $\$ 30$ in gain per share in example 7 need not be reported until 1995, when the long and short positions were closed, even though the investor had completed eliminated any possibility of further gain or loss in 1991. Congress amended the tax law in 1997 to provide for constructive sales treatment for certain appreciated financial positions, including short sales against the box and forward contracts to deliver property held by the taxpayer. ${ }^{17}$

\section{Debt Exchangeable into Corporate Stock}

In recent years, corporations holding substantially appreciated stock in another company have developed instruments that are intended to produce cash without triggering gain for tax purposes. One such product is debt exchangeable for corporate stock:

Example 8: P, a public company, issues $\$ 100$ of debt with a coupon rate of

\footnotetext{
16 IRC \$1221 (codifying and extending previous Treasury Regulations).

17 IRC $\$ 1259$.
} 
5 percent, which debt is mandatorily exchangeable at maturity into shares of A, an unrelated public company, in which $\mathrm{P}$ holds substantially appreciated shares. When the debt is issued, a share of A stock, which pays no dividends, is trading for $\$ 100$. At maturity, the holder of $\$ 100$ of the exchangeable debt will receive one share of A stock if that stock is trading at $\$ 100$ or lower; $\$ 100$ worth of $A$ stock if it is trading between $\$ 100$ and $\$ 120 ;$ and five-sixths shares if the $A$ stock is trading at $\$ 120$ or higher.

The exchangeable debt in this example could be analyzed as a current sale of the A stock by $P$ (which would trigger immediate gain to $\mathrm{P}$ ), as a prepaid forward sale of the A stock (which would defer realization until settlement), as "contingent debt" (which could be subject to expected value taxation described below, including the deduction of OID by issuer in addition to the 5\% coupon rate), or as a combination of non-prepaid forward and a security deposit. No specific provision of the Code or regulations applies as yet to exchangeable debt, so the tax consequences depend on the applicability of many of the provisions described above, relating to straddles, constructive sales, and so on. ${ }^{18}$

Practitioners [e.g., Schizer, (2000a)] often take the position that they can control the results under these provisions by carefully modifying the details of the transaction, including, for example, a fixed return if characterization as debt is desired.

A variation on this type of instrument involves debt exchangeable for the common stock of a related corporation:

Example 9: S, the subsidiary of a public company $P$, issues debt, which is convertible into stock of $\mathrm{P}$ at the option of the holder at a designated price. At issuance, $P^{\prime}$ s stock price is substantially below the designated price.

\footnotetext{
18 Proposed Treasury Regulations \$1.263(g)-4 (2001) would require interest payments on some exchangeable debt to be capitalized as part of a straddle.
} 
Here the goal is not to realize cash on an appreciated position, but to achieve interest deductions for what will be an equity instrument. Deductions for interest on instruments on which principal or interest is payable in stock of the issuer or a related party have been disallowed since 1997, but only if there is a substantial certainty that the option will be exercised. ${ }^{19}$

\section{Conversion of Ordinary Income into Capital Gain}

Differential treatment of capital gains and ordinary income has long stimulated taxpayer attempts to convert the latter into the former, giving rise to particularized legislative responses. For example, the Internal Revenue Code has long provided that short sale of, or purchase of a put on, a short-term capital asset closes the holding period, so that short-term gains cannot be converted into long-term gains. ${ }^{20}$

Legislation enacted in 1993 provides for recharacterization of some capital gain as ordinary income in certain conversion transactions. ${ }^{21}$ Such transactions involve more than one position with respect to the same or similar property, which positions result in substantially all the expected return from the investment being attributable to the "time value" of the taxpayer's net investment. In such a case, gain up to 120 percent of a compounded

\footnotetext{
19 IRC $\$ 163(1)$.

20 IRC $\$ 1233$.

21 IRC $\$ 1258$.
} 
applicable federal interest rate is considered ordinary income.

The following example is adapted from the legislative history:

Example 10: Assume that $X$ purchases stock for $\$ 100$ on January 1, 1994, and on that same day agrees to sell it to $Y$ on January 1, 1996 for $\$ 115$. Assume further that the applicable federal rate is 5\%. On January 1, 1996, X delivers the stock to $Y$ in exchange for $\$ 115$ in satisfaction of their agreement. Under prior law, $X$ would have recognized a capital gain of $\$ 15$. Under the new provision, $\$ 12.36$ of that amount would be recharacterized as ordinary income (i.e., 120\% of 5\% compounded for two years applied to an investment of $\$ 100)$.

Legislation enacted in 1999 further limits conversion of ordinary income into capital gain in certain constructive ownership transactions, in which the taxpayer has a long position (such as a forward contract) in an underlying financial investment (such as hedge fund organized as partnership). ${ }^{22}$ The amount of long-term capital gain is limited to the amount of such gain the taxpayer would have recognized if he had held the underlying investment, with any excess treated as ordinary income and subject to an interest charge. The following example is again adapted from the legislative history:

Example 11: On January 1, 2000, Taxpayer enters into a notional principal contract with a securities dealer, under which the dealer agrees to pay Taxpayer the amount of any increase in the value of a $\$ 1$ million interest in a certain investment partnership in three years. In exchange, Taxpayer agrees to pay the dealer the amount of any decline in value of that interest. After three years, the value of the underlying investment has increased by $\$ 200,000$, of which $\$ 150,000$ is attributable to ordinary income and net short-term capital gain. The remaining $\$ 50,000$ is attributable to net long-term capital gain. Under the new provision, $\$ 150,000$ of gain on the contract that might otherwise be capital gain is recharacterized as ordinary income and subject to an interest charge.

\section{Derivatives on a Corporation's Own Stock}

Corporations generally do not recognize gain or loss from

22 IRC $\$ 1260$. 
transactions involving their own stock or, since 1984, options on their own stock. ${ }^{23}$ At the time of the 1984 amendment, Congress focused on sales by companies of warrants, which are call options on a company's own stock. In recent years, public corporations have greatly expanded the use of derivatives on their own stock. Companies such as Microsoft have sold puts on their own shares, which produce nontaxable corporate gain if share prices rise. Although less common, some companies purchase calls on their own stock, which also produce nontaxable gain if share prices rise. Still other companies may have used derivatives, such as swaps, which have the same substantive results as options, but which are not subject to the nonrecognition provision adopted in 1984 . Although the motivation for these developments is not entirely clear, Gibson and Singh (2001) suggest that selling puts can reduce financing costs by signaling investors that management has favorable nonpublic information about the company's prospects, while Chacko et al. (2000) suggest that buying calls can be a means of hedging cash flows.

Although gains and losses on the purchase and resale of stock have no tax consequences for the issuing corporation, interest received pursuant to the current sale of a corporation's own stock for future delivery is taxable. More favorable results can be obtained if a corporation makes a forward sale of its own stock: 
Example 12: Corporation $C$ uses $\$ 1000$ in liquid assets, which had been producing an annual taxable return of 10 percent, to purchase ten shares of its own stock for $\$ 1000$. At the same time, C enters into a forward sale of 10 shares of its stock for delivery in one year for $\$ 1100$.

The effect of this transaction is to convert $\$ 100$ of corporate taxable income into nontaxable gain. A corporation which borrowed $\$ 1000$ to purchase the shares in example 12 would have $\$ 100$ in deductible interest when it used the proceeds from the forward contract to repay the debt. Legislative proposals of the clinton Administration would have required that a corporation entering into a forward contract for the sale of its own stock treat a portion of the payment received as interest. (Joint Committee 2000)

One view of current law is that the 1984 amendment was illadvised, because gains and losses on options on a company's own stock make shareholders of the issuing company better or worse off relative to other taxpayers. Another view. [e.g., New York State Bar Association (1999)] is that the corporate income tax should be limited to operating business income, so the exclusion for options should be extended to other derivatives on a company's own stock Still another possibility would be to limit the exemption to derivatives settled in kind, rather than cash.

Each of these possibilities would involve potential inconsistencies with the taxation of other transactions. Part of the rationale for the 1984 change was to conform the treatment of cash settlements to the results of actually issuing or repurchasing the stock. Failure to include other derivatives in the scope of 
these provisions creates other discontinuities today. Restriction of taxable income to regular business operations would seem inconsistent with the longstanding inclusion in corporate income of gain on cancellation of indebtedness when bonds are repurchased for less than their issue price.

Finally, an alternative perspective suggests that corporate transactions in derivatives on the corporation's own stock can be tax-disadvantaged under current law, in spite of the exclusion of gain. Put-call parity indicates that selling a call and writing a put at the same strike price (which aggregate to selling the share forward) is equivalent to borrowing to buy a share of the stock. From that perspective, McDonald (2001) suggests that companies currently buying calls and selling puts on their own stock are failing to take advantage of the interest deduction available for equivalent transactions.

Example 13: Company $X$ is considering two possible courses of action: (a) Under the first alternative, $\mathrm{X}$ would borrow $\$ 1000$ in year 1 at 10 percent interest to purchase its own stock, with the debt to be repaid by selling the stock in year 2. (b) Under the second alternative, $X$ would enter into forward contracts in year 1 to buy its stock in year 2 for $\$ 1100$. (Equivalently, $\mathrm{X}$ could buy calls and sells puts on its stock in year 2 with a strike price of \$1100.) X will have exactly the same gains and losses apart from taxes under either course of action. If, for example, the stock is worth $\$ 1500$ in year 2 , $\mathrm{X}$ will have a gain of $\$ 400$ in either case. If the stock is worth $\$ 700$ in year 2 , $\mathrm{X}$ will have a loss of $\$ 400$ in either case. The tax consequences will, however, differ, because $\$ 100$ of interest will be deductible under alternative (a), but not (b).

\section{Payments to Foreign Investors}

Like most developed countries, the U.S. taxes some, but not all, categories of U.S.-source investment income paid to foreign investors who are not engaged in a trade or business here. 
Dividends on stock in U.S. companies are, for example, subject to a withholding of 30 percent (or less if reduced by treaty), ${ }^{24}$ while portfolio interest is not taxed at all. ${ }^{25}$ Capital gains on U.S. real estate are taxed, while capital gains on stock in U.S. companies (other than real property holding companies) are not. Under the standard tax treaty, income that does not fall into a specified category is considered "other income," which is sourced in the country of the recipient, so such payments originating in the U.S. would not be subject to U.S. taxation if made to foreign investors. These kinds of distinctions can be undermined by financial derivatives.

By way of illustration, we will consider three methods for obtaining the economic benefits of dividends paid by U.S. companies without incurring the withholding tax: securities lending, total return swaps, and synthetic equity. [For further examples, see May (1996), Colon (1999a), and Thuroyni (2001).]

Example 14: F, a foreign investor, lends stock in U.S. companies to D, a U.S. securities dealer, in exchange for a contractual promise to return substantially identical securities in the future plus an amount equal to any dividends paid in the interim, minus a fee for the transaction.

Treasury regulations finalized in 1997 now provide that substitute dividend payments such as those in example 14 will be sourced in the same manner as the dividends paid on the underlying

\footnotetext{
24 IRC $\$ 1441$.

25 IRC $\$ \$ 871(\mathrm{~h}), 881(\mathrm{c})$.
} 
securities. ${ }^{26}$

Example 15: F, a foreign investor, and D, a U.S. securities dealer, enter into a total return swap, under which $F$ pays $D$ a fixed rate of interest and an amount equal to any decline in the value of $A B C$ stock. D pays $F$ an amount equal to dividends paid on the stock plus any appreciation in the value of the stock. $F$ hedges its exposure by purchasing a bond; D hedges its exposure by purchasing share of $\mathrm{ABC}$.

Although the Treasury has expressed concerns about such transactions, it has so far not extended the "look through" approach from securities=lending to swaps. Finally, our earlier discussion of put-call parity showed how equity investments can be replicated using derivative contracts:

Example 16: The stock of USCO, on which a $\$ 4$ dividend is expected a year, is currently trading at $\$ 100$ a share. In year $1, F$, a foreign investor, buys a $\$ 100$ U.S. Treasury bond paying a riskless return of 6 percent and enters into a cash-settled forward contract to buy 100 shares of USCo for $\$ 102$ in year 2. (The forward price is the current share price (\$100) plus the riskless return (\$6) minus the expected dividend (\$4).)

Assuming that USCo pays the expected dividend, $F^{\prime}$ s position in year 2 in example 16 will be identical in value to what it would have been, had he purchased of 100 shares of USCo in year 1 . In either case, the total value will be the year 2 value of the Usco stock plus $\$ 4$. Although an actual purchase of USCo stock would trigger a withholding tax on the dividend, the synthetic equity will produce no U.S. taxation. Interest on the bond is exempt portfolio interest, while gain on the forward will be foreignsource.

\section{Foreign Currency Transactions}

26 Treas. Reg. $\$ 1.861-3(a)(6)$. 
Since 1986, the Internal Revenue Code has provided an elaborate regime for taxation of gain and loss due to changes in the value of foreign exchange, relative to the dollar. ${ }^{27}$ Unless one of the provisions discussed above applies, such gain or loss is generally taxed on realization and is usually ordinary, rather than capital. In some cases, this regime integrates hedges of foreign currency with offsetting transactions, such as loans, in order to prevent inconsistent treatment of related cash flows. ${ }^{28}$ The following example is adapted from the Treasury regulations. ${ }^{29}$

Example 17: A, a U.S. taxpayer, borrows 100 British pounds for a period of three years at a fixed rate of interest, payable annually with principal payable at the end of the loan. A simultaneously enters into a currency swap agreement, under which A swaps the borrowed pounds for dollars and agrees to exchange dollars for pounds pursuant to a fixed schedule in order to make the future payments in pounds. The pound borrowing and swap contract will be integrated into a synthetic dollar borrowing.

\section{Evaluation}

As illustrated by the foregoing examples, the traditional tax law response to financial innovation has been reactive and particularized. Specific regulations or legislation have been adopted in order to conform the treatment of new transactions to familiar paradigms. An obvious problem with this piecemeal response is that the Treasury is always scrambling to catch up with the developers of new products. Even today, there are many wellknown financial transactions for which the appropriate tax

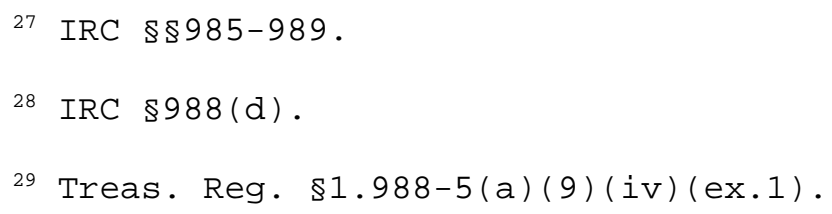


treatment remains uncertain. Examples include prepaid forwards, deep-in-the-money options, and contingent nonperiodic payments under notional principal contracts. One reason for the delay and uncertainty is that the traditional approach is often indeterminate, because different disaggregations will often be possible. Weisbach (2000) argues that such line drawing will always be necessary in a realization-based tax, and that the resulting distinctions should be drawn explicitly on efficiency grounds.

\section{B. Taxation of Changes in Market Values}

In recent years the tax law has required (or permitted) current taxation of changes in market value (generally known as mark-to-market taxation) in for limited categories of financial contracts: (1) regulated futures contracts, foreign currency contracts, nonequity options, and dealer equity options (since $1981) i^{30}$ (2) securities held by dealers for sale to customers (since 1993) $i^{31}$ and (3) securities and commodities held by traders (optionally since 1997). ${ }^{32}$ Gains and losses in the first category (other than by securities dealers) are treated as 40 percent shortterm capital gains or loss and 60 percent long-term capital gain or loss.

30 IRC $\$ 1256$.

31 IRC $\$ 475$.

32 Id. The Treasury has also considered mark-to-market treatment for certain foreign currency gains and losses. Prop. Regs. \$ 1.988-5 (f) (1992). 
In 1998, the Financial Accounting Standards Board issued Statement of Financial Accounting Standard No. 133 (FAS 133), which requires that derivatives be shown on the balance sheet as assets or liabilities at market value. Changes in market value are to be reflected in earnings. Embedded derivatives must be disaggregated and shown separately if they are not sufficiently related to the host instrument. When a derivative is used as a hedge, FAS 133 allows certain hedged items also to be marked to market. FAS 133 specifically rejects integrating different positions into a single financial instrument.

Some commentators [e.g., (Ensminger 2001)] have urged the tax system to follow the lead of the accounting profession in FAS 133. Others have pointed out that unless all assets are marked to market, new discontinuities will be created. Finally, still others [e.g., Schizer (2000b)] have argued that even the current extent of marking to market for tax purposes has created new problems, because dealers have become accommodation parties in transactions that artificially defer income for one taxpayer while accelerating it for another. Marking to market leaves dealers, like tax-exempt institutions, unaffected by acceleration or deferral of income.

\section{Formulaic Taxation}

Seven methods of imputing a rate of return on investment assets have been proposed to reduce the advantages of deferral under realization income taxation. These proposals are generally 
extensions of the yield-to-maturity formula that applies to fixedreturn instruments. The seven methods fall into two general categories: (1) investment-specific rates, and (2) generally applicable rates.

\section{Investment-Specific Rates}

\section{a. Expected Value Taxation was first proposed as a}

general approach by shuldiner (1992). The basic idea is that every contingency has an expected future value, and the difference between present value and that future value should treated as OID, with contingencies taxed on resolution:

Example 18: I pays J $\$ 100$ today; in exchange, J promises to pay I either $\$ 166$ or $\$ 100$ in three years depending on the toss of a coin at that time. The expected value of the contract in year 3 is $\$ 133$, because there is a $50 \%$ probability of receiving $\$ 100$ and a 50\% probability of receiving $\$ 166$. That expected value implies an expected gain of $\$ 33$ and a yield-to-maturity of $10 \%$, because $\$ 100 \times(1.1)^{3}=\$ 133$, so the taxable income would be allocated $\$ 10$ to year 1, \$11 to year 2, and $\$ 12$ to year 3, as in example 1. I would include, and J would deduct, those amounts each year. I's basis would then be $\$ 133$, and gain or loss on the coin toss would be taken into account in year 3 .

After the Treasury had proposed the different approaches to contingent debt described above after example 5, the regulations eventually adopted a form of expected value taxation. ${ }^{33}$ Under the 1996 noncontingent bond method, the issuer determines its

comparable yield for noncontingent debt, which is then applied to a projected payment schedule. The issuer and holder accrue interest in accordance with the projected schedule, making adjustments for actual payments that differ from the projection. If the contingency is based on market information, the 
comparable yield can be determined by constructing a hedge that eliminates the contingency. Projected payments include both fixed payments and any contingency's forward price, which can be the spot price of a similar exchange-traded option compounded to the date of payment. Assuming in example 5 that the spot price on issuance of the right to receive the contingent amount was $\$ 379$, the hedged instrument would bear OID of 10 percent, because issuer would be obligated to pay $\$ 1000$ in 5 years in exchange for a current net receipt of $\$ 621$. The projected payments would include the fixed payment of $\$ 1000$ plus the projected payment of $\$ 610$ (i.e., \$379 $\left.(1.1)^{5}\right)$, so interest would accrue on the entire investment of \$1000, as was true under the 1993 Treasury proposal, even though separate issuance of a discount bond and an cash settled option would not be so treated. This aspect of the contingent debt regulations has been controversial [e.g., (Schizer 2000a)], because it creates arbitrage opportunities.

When the contingency is not based on market information, the issuer is nevertheless required to identify a comparable yield and an expected payment schedule. The breadth of the approach is indicated by the following example from the regulations:

Example 19: Non-market-based payments--(i) Facts. On December 31, 1996, Y issues to $Z$ for $\$ 1,000,000$ a debt instrument that matures on December 31 , 2000. The debt instrument has a stated principal amount of $\$ 1,000,000$, payable at maturity, and provides for payments on December 31 of each year, beginning in 1997, of $\$ 20,000$ plus 1 percent of $Y^{\prime}$ s gross receipts, if any, for the year. On the issue date, $Y$ has outstanding fixed rate debt instruments with maturities of 2 to 10 years that trade at a price that reflects an average of 100 basis points over Treasury bonds. These debt instruments have terms and conditions similar to those of the debt instrument. Assume that on December 31, 1996, 4-year Treasury bonds have a yield of 6.5 percent, compounded annually, and that no \$1.1275-6 hedge is available for the debt instrument. In addition, assume that the 
interest inclusions attributable to the debt instrument are expected to have a substantial effect on Z'S U.S. tax liability.

(ii) Comparable yield. The comparable yield for the debt instrument is equal to the value of the benchmark rate (i.e., the yield on 4-year Treasury bonds) on the issue date plus the spread. Thus, the debt instrument's comparable yield is 7.5 percent, compounded annually.

(iii) Projected payment schedule. Y anticipates that it will have no gross receipts in 1997, but that it will have gross receipts in later years, and those gross receipts will grow each year for the next three years. Based on its business projections, $Y$ believes that it is not unreasonable to expect that its gross receipts in 1999 and each year thereafter will grow by between 6 percent and 13 percent over the prior year. Thus, Y must take these expectations into account in establishing a projected payment schedule for the debt instrument that results in a yield of 7.5 percent, compounded annually. Accordingly, Y could reasonably set the following projected payment schedule for the debt instrument:

Date

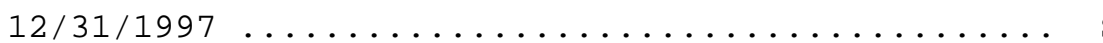

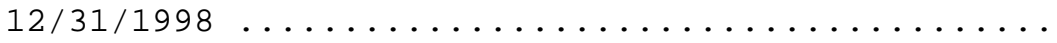

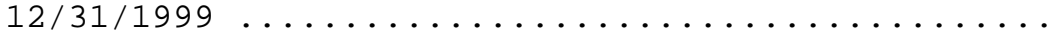

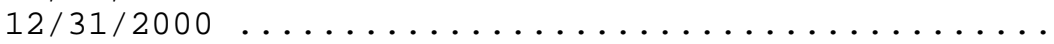

Noncontingent Contingent payment payment

20,0000
20,000
20,0000
020,0000

Some commentators [e.g., Edgar (2000)] propose extension of the scope of expected value taxation in order to reduce discontinuities due to deferral of unrealized appreciation under current law. A preliminary step might be to extend this treatment to prepaid forwards and deep-in-the-money options, a step that has apparently been under consideration in the Treasury. A further extension, which would presumably require legislation, would be to apply expected value taxation to options generally Under this approach, anticipated gain on assets with likely future payments would be taxed as OID, whereas unanticipated gain due to changes in market values would be taxed on realization, perhaps as capital gain. Selective realization would therefore continue to be an issue with respect to unanticipated gain, so 
there would still be a need for loss limitations and other integration devices.

\section{b. Retrospective Allocation of Gain: A different}

approach would be to impose an interest charge on receipt of payments that are considered deferred. Different versions of this approach for contingent-return assets have been suggested over the years [e.g., Vickrey (1939), Blum (1988), Fellows (1990)], and Congress has embraced the idea in certain instances. ${ }^{34}$ Consistent with yield-to-maturity taxation, it has, for example, been suggested that retrospective allocation could be made on a compounded basis:

Example 20: Investor $H$ purchases an asset for $\$ 100$ at the beginning of year 1 and sells it at the end of year 3 for $\$ 200$. The implicit compounded rate of return is $26 \%$, because $\$ 100 \times(1.26)^{3}=\$ 200$. Given a tax rate of $30 \%$ the income would have compounded at $18.2 \%$ after taxes if taxes had been paid currently, for a final asset value of $\$ 165.14$. This same result could be achieved retrospectively by charging a deferred tax of $\$ 34.86$ (\$200-\$165.14) on sale of the asset.

Since any such interest charge would involve an arbitrary allocation of gain over the holding period, it would create new incentives for selective realization. If, for example, the assets in example 20 had doubled in value by the end of year 1, deferral of sale until year 3 would be advantageous even with retrospective allocation of gain.

\section{c. Continuous Yield-to-Maturity: Land (1996) suggested}

that the advantages of selective realization would be eliminated

\footnotetext{
${ }^{34}$ See, e.g, IRC $\$ 453$ (1) (3) (timeshares), IRC $\$ 460$ (b) (completed contract method), IRC \$668(a) (distribution from foreign trusts), IRC \$1291(a) (passive foreign investment companies), IRC \$1260 (conversion transactions).
} 
if yield-to-maturity taxation were applied at sale as in example 20, but on the assumption of continuous compounding. On this assumption, after $\mathbf{n}$ periods at a rate of interest $\mathbf{i}$, the instrument's sale value $\mathbf{S}$ is related to the purchase price $\mathbf{P}$ as follows: $S=P e^{n i}$.

Accordingly, $\$ 1000$ invested at 10 percent will be worth $\$ 2718$ after 10 years. If a 30 percent tax had been collected as the interest compounded, the after-tax rate of return would have been 7 percent annually, which would have yielded $\$ 2014$ after 10 years with continuous compounding, because $\mathrm{n} \times(1-t) i=.7$, and $e^{\cdot 7}=$ 2.014. The same result could be accomplished retrospectively by charging the taxpayer the difference (\$704) between the pre-tax and after-tax return on sale of the asset.

The amount due the government under this approach (\$704) is independent of how long it takes an investment of $\$ 1000$ to grow to \$2718. That is, the result is independent of both the interest rate and the length of the investment. Given continuous compounding, the tax (T) is simply a function of the tax rate, the purchase price (P), and the sales price (S): $\mathbf{T}=\boldsymbol{S}\left[1-\left(\boldsymbol{S} / \boldsymbol{P}^{-t}\right]\right.$.

Example 21: The investor purchases an asset for $\$ 1000$ and sells it for \$2718. If the tax rate is $30 \%$, $\$ 704$ in taxes are due, no matter how long the asset has been held.

As the tax is independent of the holding period, it is not affected by a decision of when to sell, thereby eliminating the problem of selective realization. For Land, the logic of the tax 
is that the government becomes an equity partner in the investment, entitled to its share of the yield. For assets with declining values, this approach reduces the tax benefit of the loss as the loss increases. An investment of $\$ 1000$ that became worthless would, for example, produce no refund.

Land points out two other major problems with the yield approach. First, it does not work well with assets that have more than one cash flow, because either all taxation must be deferred to the last cash flow (which might be very small) when the yield can be determined or the asset must be revalued when intermediate cash flows are received. Second, the method is not linear, in that the sum of the taxes on two separate investments is generally not equal to the tax that would be imposed on the same two investments viewed as a single unit. Accordingly, he proposes imposing the yield-based tax on the investor's entire portfolio, rather than on individual investments. Under this approach, taxation and revaluation would be triggered on withdrawal (or investment) of cash.

\section{A Generally Applicable Rate of Return}

The three methods of imputing a return discussed so far have all involved a rate specific to the investment asset. We now turn to four proposals that involve a generally applicable rate.

a. Imputing Interest on Basis: One possibility would be to impute a standard rate of return on the basis of some class of assets, as suggested by Cunningham and Schenk (1992). Here the 
imputation would occur every year at the then current market rate, so that unlike OID or expected value taxation, part of the unanticipated change in market value (that due to changes in interest rates) would affect taxation currently. Other changes in market value would not be taken into account, so selective realization could still be an issue.

b. Taxation at the Riskless Rate: A different approach, first proposed by Auerbach (1991), would be to tax dispositions as if they had resulted in gains accruing at the riskless rate of return:

Example 22: Consider an asset that is purchased at the end of year 0 and sold at the end of year 2 for $\$ 121$. The riskless rate of return is $10 \%$ and the tax rate is $30 \%$. Given the assumed rate of return of $10 \%$, the purchase price two years earlier would have been $\$ 100$ (i.e., $\$ 121 /(1.1)^{2}$ ), which would have produced $\$ 10$ of income in year 1 and $\$ 11$ in year 2. The total tax due on sale (\$6.51) in year 2 would be the sum of: (a) $\$ 3$ in taxes on the assumed year 1 gain (\$10) compounded at the after-tax rate (7\%) to $\$ 3.21$, and (b) $\$ 3.30$ in taxes on the assumed year 2 gain (\$11). After paying taxes, the investor would retain $\$ 114.49$, which is a compounded after-tax return of 7\% on the assumed investment of $\$ 100$. The actual purchase price of the asset, whether higher or lower than its sales price, does not enter into the calculation.

With continuous compounding, the general expression for the amount of the tax is $\mathbf{T}_{\mathbf{s}}=\left(\mathbf{1}-\mathbf{e}^{- \text {tis }}\right) \mathbf{A}_{\mathbf{s}}$, when $\mathbf{T}$ is the tax due at date $\mathbf{s}$ for an asset worth $\mathbf{A}$ on that date, given an interest rate of $\mathbf{i}$ and a tax rate of $t$. One criticism this approach is that it does not result in a tax on actual gain. On the other hand, this approach is consistent with the view that a income tax only taxes the riskless rate of return on capital. (Kaplow, 1994)

C. Arbitrary Gain Recognition Date: Bradford (1995) proposed that the amount realized on sale of an asset be discounted back at the riskless rate to an arbitrary gain recognition date (GRD), 
which would be set in advance. Cost basis would be compounded forward to the same GRD, and gain or loss computed as of that date would be taxed at the gain tax rate (GTR), which would also be set in advance. That tax would then be compounded forward (at the after-tax rate) to the date of sale, as would taxes on the imputed return before and after the GRD. Selective realization is avoided under this approach because the tax due does not depend on the actual date of sale.

Example 23: Consider an asset purchased at the end of year 0 for $\$ 100$, and sold at the end of year 2 for $\$ 231$. The end of year 1 is chosen as the GRD, the riskless rate of interest is 10 percent, and, for simplicity, the tax rate on both ordinary income and capital gain is 30 percent. The amount realized of $\$ 231$ in year 2 would be discounted at $10 \%$ to $\$ 210$ at the GRD, and cost basis of $\$ 100$ would be compounded at $10 \%$ to $\$ 110$ at the GRD, producing a gain of $\$ 100$ and a tax of $\$ 30$ at the end of year 1 . The total tax payable on realization of $\$ 131$ in gain at the end of year 2 would be the sum of: (a) the tax of $\$ 30$ levied on $\$ 100$ of gain at the GRD compounded for one year at the after-tax rate (7 percent) to $\$ 32.10$, (b) a tax of $\$ 3$ on the $\$ 10$ of imputed return in year 1 compounded for one year to $\$ 3.21$, and (c) a tax of $\$ 6.30$ on $\$ 21$ of imputed return in year 2 .

With continuous compounding, the tax payable at realization date s on an extra dollar's worth of sales proceeds would be 1-(1GTR) $\mathbf{e}^{-\mathbf{m r}(\mathbf{s}-\text { GRD)}}$, where $\boldsymbol{r}$ is the rate of interest and $\mathbf{m}$ is the marginal rate of taxation on such interest.

Unlike the Auerbach approach, this system of taxation does result in a tax on the actual gain, albeit as of an arbitrary date. Of course, taxation of the gain on the date of realization can also be regarded as arbitrary. Like current law (and unlike the Auerbach approach), this system requires the taxpayer to keep track of cost basis.

d. Generalized Cash Flow Taxation: Auerbach and Bradford 
(2001) combines and generalizes the two previous approaches into a system that effectively taxes capital income at a uniform rate, but without requiring the taxpayer to keep track of basis. One way to understand this proposal is to recall that under standard assumptions cash flow taxation, unlike income taxation, imposes an effective tax rate of zero on capital income from marginal investments when the same rate of tax is applied to all cash flows. (Warren, 1996) Applying a higher rate of tax on (later) disinvestments than on (earlier) investments would impose a burden on capital income. Accordingly, if tax rates on cash flows increased by just the right amount between purchase and disposition of an asset, results equivalent to accrual taxation of capital income from marginal investments could be achieved.

Example 24: Consider a taxpayer who invests $\$ 100$ in year 1 at a riskless rate of return of 10 percent, and then sells the asset in year 2 for $\$ 110$. An income tax of 30 percent would reduce the riskless return to 7 percent after taxes. The same result could be accomplished by imposing a cash flow tax of 40 percent in year 1 and 41.64 percent in year 2. The investor could gross-up his investment to $\$ 166.67$ (i.e., $\$ 100 / .6$ ) due to the year 1 tax savings. That investment would be worth $\$ 183.33$ in year 2 (\$166.67 x 1.1) before taxes, producing taxes of $\$ 76.34(\$ 183.33 \mathrm{x} .4164)$, leaving the investor with $\$ 107$ after taxes.

The general expression for the tax rate payable on cash flows at date $\mathbf{v}$ would be $1-(1-g)[1+i(1-t) /(1+i)]^{(\mathbf{v}-\mathbf{D})}$, where $\mathbf{i}$ is the rate of interest, $t$ is the marginal rate of taxation on such interest, $\mathbf{v}$ is the date of the cash flow, $\mathbf{D}$ is the gain recognition date, and $\mathbf{g}$ is the rate of tax on the gain. ${ }^{35}$

Under the Bradford approach, an asset's cost and sales price

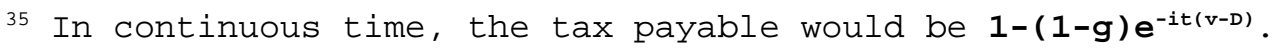


are compounded and discounted to the same date for deduction and inclusion at the same tax rate. Auerbach and Bradford accomplish the same results by deducting and including cost and sale price at different dates, with the applicable tax rates modified to take into account the difference in dates. Both approaches thus tax gains discounted to the GRD at the GTR and imputed interest before and after the GRD at the rate of tax applicable to interest.

Example 25: Consider a taxpayer who purchases an asset for $\$ 100$ at the end of year 0 . The asset doubles in value and is sold at the end of year 1. The interest rate is 10\%, and the tax rate on interest income is 30\%. A cash flow tax of 40 percent in year 0 would produce a grossed-up purchase of $\$ 166.67$ in year 0 and pre-tax proceeds of $\$ 333.34$ in year 1 . If a cash flow tax of 41.64 percent were applied to the sale proceeds in year 1 , the investor would have $\$ 194.54$ after taxes. This is the same result as would obtain under the Bradford approach, assuming year 0 were the GRD. In order to make a comparable investment, the taxpayer would borrow $\$ 66.67$ at $10 \%$ to invest $\$ 166.67$. The sales price of $\$ 334.34$ would be discounted to $\$ 303.04$ in year 0 , producing taxable gain of $\$ 136.37$ (\$303.04-\$166.67) and a tax of $\$ 54.55$, which would compound to $\$ 58.37$ in year 1 . The total tax due in year 1 would be $\$ 67.46$ (\$58.37 plus $\$ 9.09$ on the $\$ 30.30$ in year 1 imputed interest). The taxpayer would again be left with $\$ 194.54$ after paying taxes (\$67.46), loan principal $(\$ 66.67)$, and after-tax interest $(\$ 4.67)$ out of sale proceeds of $\$ 334.34$.

Auerbach and Bradford show that their approach, which they style generalized cash flow taxation, is the only form of realization taxation that will result in a uniform capital income tax, or, equivalently, a uniform wealth tax. Since this method applies directly to cash flows, it could reduce many of the discontinuities of current law discussed above, which result from differential treatment of equivalent cash flows.

\section{Anti-avoidance Provisions}

In recent years, a number of transactions, some of which involve financial derivatives, have come to be known as corporate 
tax shelters. [Bankman, (1999)] These transactions, which are often based on a literalist reading of the code or regulations, generally promise substantial tax savings with very little nontax financial return. The courts and Congress have reacted in part by applying or strengthening certain "anti-avoidance" rules.

The Internal Revenue Code contains provisions that authorize disallowance of tax benefits in certain transactions motivated by tax avoidance, ${ }^{36}$ where the taxpayer's method of accounting does not clearly reflect income, ${ }^{37}$ if the parties are related, ${ }^{38}$ and in the case of certain multi-party conduit transactions. ${ }^{39}$

There are also longstanding judicial decisions that prohibit "sham transactions," mandate a business purpose, provide that a transaction be taxed in accordance with its substance rather than its form, and require "economic substance." One interpretation of this last requirement is some level of pre-tax profit; another is a quantitative comparison of the tax and nontax benefits of a particular transaction. The "contingent installment sale transaction" is an example of a corporate tax shelter that the courts have disallowed, relying on such doctrines: ${ }^{40}$

Example 26: In 1988, C reported a \$100 million capital gain. In 1989,

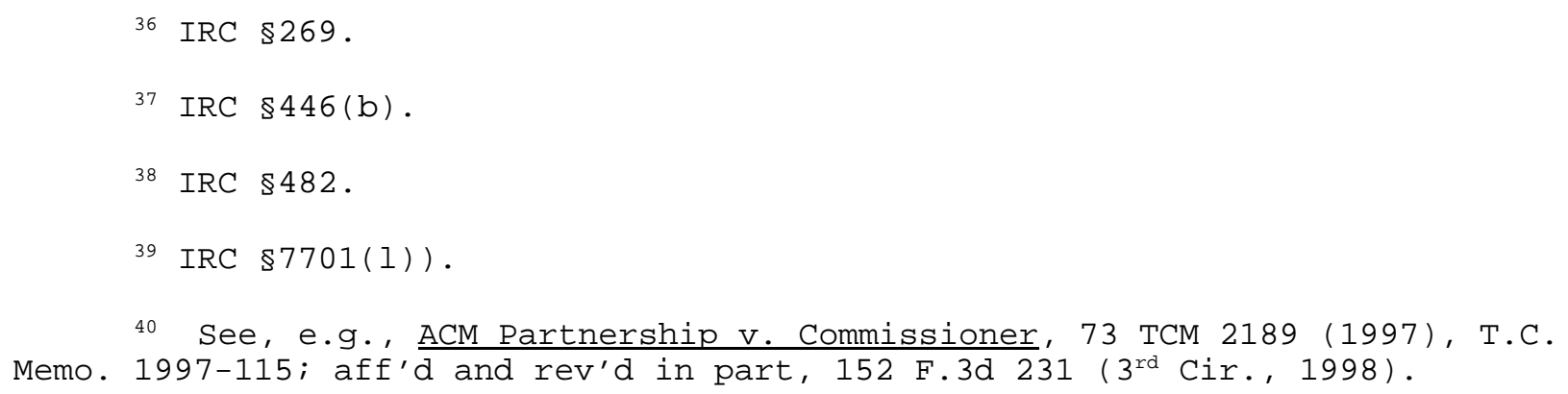


pursuant to the advice of $M$, an investment banking firm, A (a foreign entity), $C$, and $M$ created an offshore partnership $\mathrm{P}$, in which their respective initial interests were 81\%, 18\%, and 1\%. Using cash contributed by the partners, $P$ purchased securities for $\$ 200$ million and shortly thereafter sold virtually all of those securities for $\$ 150$ million in cash and notes worth $\$ 50$ million payable over the following 3 years subject to certain contingencies. P reported the transaction in accordance with regulations providing that where a maximum sales price could not be determined, cost basis should be spread equally over the period of the transaction). Accordingly, \$100 million of capital gain ( $\$ 150$ million cash receipts minus $\$ 50$ million of allocated basis) would be recognized in the first year, and mostly allocated to A, which was not subject to U.S. taxation. A's partnership interest in $\mathrm{P}$ was then redeemed. In the three subsequent years, P reported $\$ 100$ million of capital loss (\$50 million of cash receipts minus $\$ 150$ of remaining basis), most of which was allocated to $\mathrm{C}$, which carried that loss back to offset its previous capital gain.

There are also some regulatory provisions that give the government wide discretion to reformulate transactions. For example, if a partnership is used to reduce taxes in a manner that is inconsistent with the intent of the partnership provisions, the government can (since 1995) recast a transaction so that the result is consistent with the statutory intent. ${ }^{41}$

In 1997, Congress enacted new disclosure requirements for corporate tax shelters in order to discourage taxpayers from entering into questionable transactions and to give the government earlier notice of such transactions. ${ }^{42}$ Pursuant to this legislation, the Treasury proposed regulations in 2000 that would require registration of corporate tax shelters, which are defined as transactions offered under conditions of confidentiality, where a significant purpose is the avoidance or evasion of taxes. The latter branch of the definition includes (i) certain listed

\footnotetext{
41 Treas. Reg. $\$ 1.701-2$.

42 IRC $\$ 6111(d)$.
} 
transactions (including the transaction described in example 26), (ii) those lacking "economic substance," (iii) and other "taxstructured" transactions. ${ }^{43}$ A transaction lacks economic substance if the present value of the participants' expected pretax profits is insignificant relative to the present value of the participant's tax savings. Subject to certain exceptions, a taxstructured transaction is one in which tax benefits constitute "an important part of the intended results of the transaction."

These developments suggest that an alternative (or supplementary) response to the problems discussed in this paper would be to grant more authority to tax administrators to disregard tax-motivated transactions.

\section{Summary and Conclusions}

The foregoing discussion can be summarized as follows:

1. Realization income taxation has relied on certain distinctions (e.g., fixed versus contingent returns, capital gains versus ordinary income, corporate debt versus corporate stock, domestic versus foreign source) that can be circumvented by innovative financial arrangements.

2. The traditional tax law response of transactional analysis may not be robust enough to deal with financial innovation.

3. One alternative would be to expand mark-to-market taxation considerably, which could, however, create new discontinuities unless the new system applied to all investments.

43 Treas. Temp. Reg. \$301.6111-2T. 
4. Another alternative would be to expand formulaic taxation. The major regulatory innovation to date in this regard has been the application of expected value taxation to contingent debt.

5. Yet another alternative would be to extend greater authority to tax administrators to disregard taxmotivated transactions.

The components of the U.S. income tax response to financial innovation -- disaggregation of new financial products, aggregation of related positions, mark-to-market taxation, formulaic taxation, and administrative constraints for perceived abuses -- are also generally the components of the response abroad, although the details and level of sophistication vary greatly from jurisdiction to jurisdiction. (For a review of the situation abroad, see International Fiscal Association (1995).) No country has adopted a uniform, comprehensive response to financial innovation. Many have responded, like the U.S., on a piecemeal basis. In some other countries, there is a closer connection between accounting and tax rules than in the U.S., so the tax response to financial innovation has been largely shaped by the accounting response.

\section{References}

Auerbach, A. J., 1991. Retrospective capital gains taxation. American Economic Review 81(1), 167-178.

Auerbach, A. J., Bradford, D.F., 2001. Generalized cash flow taxation. (manuscript) 
Bankman, J., 1999. The new market in corporate tax shelters. Tax Notes 83 (12), 1775-1795.

Black, F., Scholes, M., 1973. The pricing of options and corporate liabilities. Journal of Political Economy 81 (3), 637-654.

Blum, C., 1988. New role for the treasury: charging interest on tax deferral loans. Harvard Journal on Legislation 25 (1), 1-111.

Bradford, D. F., 1995. Fixing realization accounting: symmetry, consistency, and correctness in the taxation of financial

instruments. Tax Law Review 50 (4), 731-784.

Chacko, G., Tufano, P., Verter, G., 2000. Cephalon, Inc.-- taking risk management theory seriously. National Bureau of Economic Research, Working Paper No. W7748.

Colon, J. M., 1999a. Financial products and source basis taxation: U.S. international tax policy at the crossroads. University of Illinois Law Review 1999 (3), 775-844.

Conlon, S., Aquilino, V., 1999b. Principles of Financial Derivatives: US and International Taxation. Warren, Gorham \& Lamont, Valhalla, N.Y.

Cox, J. C., Rubinstein, M., 1985. Options Markets. Prentice Hall, Englewood Cliffs, N.J.

Cunningham, N. B., Schenk, D. H., 1992. Taxation without realization: a "revolutionary" approach to ownership. Tax Law Review 47 (4), 725-814.

Edgar, T., 2000. Income Tax Treatment of Financial Instruments: Theory and Practice. Canadian Tax Foundation, Toronto.

Ensminger, J. J., 2001. Concerto for piano vs. orchestra: can tax and financial accounting harmonize on hedges? Akron Tax Journal 16 (1), 23-98.

Fellows, M. L., 1990. A comprehensive attack on tax deferral. Michigan Law Review 88 (4), 722, 737-813.

Financial Accounting Standards Board, 1998. Statement of financial accounting standard No. 133 (Accounting for derivative instruments and hedging activities. Norwalk, CT.

Gergen, M. (1994). The effects of price volatility and strategic trading under realization, expected return and retrospective taxation. Tax Law Review 49 (2), 209-268. 
Gibson, S., Singh, R., 2001. Using put warrants to reduce corporate financing costs. (manuscript).

Hull, J. 1993. Options, Futures and Other Derivatives Securities, second ed. Prentice Hall, Englewood Cliffs, N.J.

International Fiscal Association, 1995. Tax aspects of derivative financial instruments. Cahiers de droit fiscal international 58b.

Joint Committee on Taxation, U.S. Congress, 2000. Description of revenue proposals contained in the President's fiscal year 2001 budget proposal (JCS-2-00)

Kaplow, L., 1994. Taxation and risk taking: a general equilibrium perspective. National Tax Journal 47 (4), 789-798.

Keyes, K. M., 1997. Federal Income Taxation of Financial Instruments and Transactions. Warren Gorham \& Lamont, Boston, MA.

Kramer, A. S., 2000. Financial Products: Taxation, Regulation, and Design, third ed. Aspen Publishers, Gaithsburg, MD.

Land, S. B., 1996. Defeating deferral: a proposal for retrospective taxation. Tax Law Review 52 (1), 45-117.

May, G., 1996. Flying on instruments: synthetic investment and the avoidance of withholding tax. Tax Notes International 13 (20), $1625-1635$.

McDonald, R. L., 2001. The Tax (dis)-advantage of firms issuing options on their stock. (manuscript)

Merton, R. C., 1973a. The relationship between put and call option prices: comment. Journal of Finance 28 (1), 183.

Merton, R. C., 1973b. Theory of rational option pricing. Bell Journal of Economics and Management Science 4 (1), 141-183.

New York State Bar Association Tax Section, 1999. Report on section 1032. Tax Notes Today (document 1999 TNT 119-22).

Rubinstein, M., Leland, H. E., 1981. Replicating options with positions in stock and cash. Financial Analysts Journal 37 (4), 63.

Schizer, D. M., 2000a. Debt exchangeable for common stock: electivity and the tax treatment of issuers and holders. Derivatives Report 1 (7), 10-18. 
Schizer, D. M., 2000b. Sticks and snakes: derivatives and curtailing aggressive tax planning. Southern California Law Review $73(6), 1339-1406$.

Shuldiner, R. H., 1992. A general approach to the taxation of financial instruments. Texas Law Review, 71 (2), 243-350.

Strnad, J., 1995. The taxation of bonds: the tax trading dimension. Virginia Law Review, 81 (1), 47-116.

Stoll, H. R., 1969. The relationship between put and call option prices. Journal of Finance 24 (5), 801-824.

Thuronyi, V., 2001. Taxation of new financial instruments. Tax Notes International, 24 (3), 261-273.

Vickrey, W., 1939. Averaging of income for income tax purposes. Journal of Political Economy 47 (3), 379-397.

Warren, A. C. (1993). Financial contract innovation and income tax policy. Harvard Law Review, 107 (2), 460-492.

Warren, A. C. (1996). How much capital income taxed under an income tax is exempt under a cash flow tax? Tax Law Review, 52 (1), $1-16$.

Weisbach, D. A., 2000. An efficiency analysis of line drawing in the tax law. Journal of Legal Studies 29 (1), 71-97. 